\title{
A Comparative Study of the Quality of Teaching Learning Process at Post Graduate Level in the Faculty of Science and Social Science
}

\author{
Uzma Shahzadi (Corresponding author) \\ Assistant Professor \\ Department of Education, University of Sargodha \\ Tel: 92-321-637-1966 E-mail: uzmashah_bzu@yahoo.com
}

\author{
Gulnaz Shaheen \\ Department of Education, University of Sargodha \\ E-mail: gulsha88@gmail.com
}

Ashfaque Ahmed Shah

Assistant Professor

Department of Education, University of Sargodha

E-mail: multanxa@gmail.com

Received: September 7, 2011

Accepted: September 22, $2011 \quad$ Published: April 1, 2012

doi:10.5539/ies.v5n2p185

URL: http://dx.doi.org/10.5539/ies.v5n2p185

\begin{abstract}
The study was intended to compare the quality of teaching learning process in the faculty of social science and science at University of Sargodha. This study was descriptive and quantitative in nature. The objectives of the study were to compare the quality of teaching learning process in the faculty of social science and science at University of Sargodha. Respondent, department and gender wise comparison was also done a sample of 92 students studying in post graduate programs and 30 teachers teaching to post graduate programs were taken from five social sciences and five science departments for data collection. Convenient sampling technique was used to select the sample. A questionnaire was developed and Pilot study was conducted to find out the reliability of the questionnaire. The reliability of the questionnaire was found to be 0.794 . The results of the study proved that there is no significant difference between the quality of teaching learning process in Science and Social Science departments at University of Sargodha. It was also concluded that there is a significant difference between teachers and students responses about the quality of teaching learning process. The findings will help the teachers to improve their teaching and instructional plans. The findings of this study will be significant to the faculties of science and social science to improve their learning environment.
\end{abstract}

Keywords: Quality, Teaching learning process, Social sciences

\section{Introduction}

Teaching learning process involves the transfer of knowledge as well as transfer of skills from the one who is disseminating knowledge and transferring the skills to the one who is receiving knowledge and skills.In any educational institution the main activity is the teaching learning process. The more effective and efficient this process is the more well-liked will be the institution. This is a complex process as both activities involve high mental processes and modification of behavior. In the past few decades this process is getting attention of educationists, philosophers, policy makers, educational managers and psychologists. The more this process is planned the more effective it will be. This process is affected by many factors including the people in school management. The globalization and technology has affected the teaching learning process a lot The indicators of the process involves following, objectives, content, methodology, environment, teacher characteristics, timetable, contact hours with instructors and using AV aids. All these indicators are addressed in the present study while comparing the quality of teaching learning process. With the passage of time quality of teaching learning process in higher educational institutions is becoming a central talk in the discussions about quality of education. As an higher 
educational institute grows and diversified, society becomes more concern about the quality of teaching learning process in that institute.

Many researches were conducted on how to improve the quality of teaching learning process? This study also focused on quality of teaching learning process and a comparison was drawn between the faculty of science and social science. Many studies showed that quality of teaching learning can be assessed by the students' performance or achievement. Only few studies were conducted on affect of availability of curriculum and text books on the quality of teaching learning process like Fuller and Clarke (1994) reviewed School Effectiveness studies in less developed countries that adjusted students' achievements for their family background and found "rather consistent school effects" in relation to availability of textbooks and supplementary reading materials. Around $50 \%$ of the reviewed studies showed significant positive associations between academic achievements and school inputs. Velez et al. (1993) reviewed 18 empirical quantitative studies at the primary level conducted in Latin America and the Caribbean mainly in the 1980s and identified that access to textbooks and other instructional materials were related positively to academic achievement. While on the other hand many other researchers like Hanushek (1995; 2005) has consistently argued that "there are no clear and systematic relationships between key inputs and student performance" (Hanushek, 1995:232). The 2005 Global Monitoring Report (UNESCO, 2005) and UNICEF (2007) include enabling inputs as one of five dimensions of quality. If inputs are, rightly in our view, considered as enabling then they can only be discussed meaningfully in terms of who they enable (context, knowledge and experience of teachers and learners) to do what (literacy, Life Skills etc.) how (participatory, learner-centered, inclusive etc.). From the review of literature it was also indicated that initiatives were taken in some directions to improve the quality of teaching learning process. This study is also conducted to know the present status of quality of teaching learning process and factors affecting the quality of teaching learning process in two faculties that are faculty of science and faculty of social science.

\section{Method}

Sample: The respondents were 122 (92 students studying in postgraduate $\& 30$ teachers) from five social science and five science departments. Following null hypotheses were developed

Ho1: There is no significant difference in gender wise quality of teaching learning process at post graduate level in the faculty of Science and Social Science at University of Sargodha.

Ho2: There is no significant difference in respondents' wise quality of teaching learning process post graduate level in the faculty of Science and Social Science at University of Sargodha

Ho3: There is no significant difference in departments' wise quality of teaching learning process post graduate level in the faculty of Science and Social Science at University of Sargodha

Questionnaire was developed and pilot study was conducted to find out the reliability of the questionnaire. The reliability was found to be .794 by applying Cronbach alpha. Data was collected and analyzed to test these hypotheses using SPSS

\section{Results}

Ho1: The One sample t-test shows that the null hypothesis "there is no significant difference between gender wise quality of teaching learning process at post graduate level in the faculty of Science and Social Science at University of Sargodha." has failed to reject at .05 level. This shows that Gender Wise there is no significant difference of quality of teaching learning process at post graduate level in the faculty of Science and Social Science at University of Sargodha.

$\mathrm{H}_{02}$ : The One sample t-test shows that the null hypothesis that "there is no significant difference between respondent wise quality of teaching learning process at post graduate level in the faculty of Science and Social Science at University of Sargodha" has been rejected at .05 level. This shows that respondent wise there is a significant difference of quality of teaching learning process at post graduate level in the faculty of Science and Social Science at University of Sargodha.

$\mathrm{H}_{03}$ : The One sample t-test shows that the null hypothesis that "there is no significant difference between department wise department wise quality of teaching learning process at post graduate level in the faculty of Science and Social Science at University of Sargodha." has failed to reject at .05 level. This shows that there is no significant difference between department wise quality of teaching learning process at post graduate level in the faculty of Science and Social Science at University of Sargodha.

\section{Discussion}

The results of this research study show that the null hypotheses "there is no significant difference between gender 
wise quality of teaching learning process at post graduate level in the faculty of Science and Social Science at University of Sargodha." has failed to reject at .05 level. As shown in table 2 that the significant value 194 was greater that .05 And this shows that gender wise there is no significant difference of quality of teaching learning process at post graduate level in the faculty of Science and Social Science at University of Sargodha. Second Null hypotheses there is no significant difference between respondent wise quality of teaching learning process at post graduate level in the faculty of Science and Social Science at University of Sargodha" has been rejected at .05 level because The significant difference was .017 that is less than .05 . This shows that respondent wise there is a significant difference of quality of teaching learning process at post graduate level in the faculty of Science and Social Science at University of Sargodha.. And the null hypotheses $\mathrm{H}_{03}$ there is no significant difference between department wise department wise quality of teaching learning process at post graduate level in the faculty of Science and Social Science at University of Sargodha." has failed to reject at .05 level. It was found that the significance difference is .488 as shown in table 6 the value is greater than .05 This shows that there is no significant difference between department wise quality of teaching learning process at post graduate level in the faculty of Science and Social Science at University of Sargodha.

\section{Conclusion and Recommendations}

This research study concluded that there is a significant difference between the responses of the teachers and students about the quality of teaching learning process. The results showed that there is a significant difference where value of Sig is lowest than the .05 and it was only in the case where respondent wise comparison was done while in other cases the value of sig. was found to be greater as compare to the .05 and the difference was not significant. This Study was delimited to the faculty of science and social science while researchers can expand the study to other faculties, departments and institutions. Some indicators can also be added to the indicators of the present study. Researchers also recommend to conduct the comparative study of quality of teaching learning process among different universities.

\section{References}

Adams, D. (1993). Defining educational quality. Improving Educational Quality Project Publication \#1: Biennial Report. Arlington, VA: Institute for International Research.

Anderson, L. (1991). Increasing teacher effectiveness. Paris: UNESCO.

Anderson, S. E. (2000). A coordinated district consultant/teacher center centre approach to school-based teacher development: The Mombasa School Improvement Project. Paper presented at the Annual Meeting of the Comparative and International Education Society, San Antonio, Texas, March, 2000.

Beeby, C. (1966). The quality of education in developing countries. Harvard University Press.

Benoliel, S., O'Gara, C., \& Miske, S. (1999). Promoting primary education for girls in Pakistan. Arlington, Virginia: USAID's Development Experience Clearinghouse.

Bergmann, H. (1996). Quality of education and the demand for education: Evidence

Castillo, Joan Joseph (2009). Convenience Sampling. [Online] Available: http://www.experiment-resources.com/convenience-sampling.html (August 17, 2011). [Online] Available: http://wiki.answers.com/Q/What is descriptive research\#ixzz2NpJf9QuC (August 17, 2011)

Larry L. Lawson. (2007). International Atlantic Economic Society 2007.

Laurillard, D. (1993, 1994). Essential aspects of teaching learning process. [Online] Available: http://www.scribd.com 5769721/ teaching learning process.

SIDA. (2000). Teacher education, teachers' conditions and motivation. Stockholm: Department for Democracy and Social Development, Education Division.

Steen, L. (1999). Numeracy: The new literacy for a data-drenched society. Educational Leadership, 57(2).

Willms, J. D. (2000). Standards of care: Investments to improve children's educational outcomes in Latin America. Paper presented at the "Year 2000 Conference of Early Childhood Development" sponsored by the World Bank, Washington, D.C., April, 2000.

Table 1. Group Statistics

Gender of the Respondents

\begin{tabular}{l|l}
$\mathrm{N}$ & Mean
\end{tabular}
Std. Deviation Std. Error Mean 


\begin{tabular}{|l|l|l|l|l|}
\hline Male & 42 & 84.1667 & 11.97949 & 1.84848 \\
\hline Female & 80 & 86.4250 & 10.49144 & 1.17298 \\
\hline
\end{tabular}

Table 2. Independent Samples Test

\begin{tabular}{|c|c|c|c|c|c|c|c|c|c|}
\hline & \multicolumn{2}{|c|}{$\begin{array}{l}\text { Levene's Test for } \\
\text { Equality of } \\
\text { Variances }\end{array}$} & \multicolumn{7}{|c|}{ t-test for Equality of Means } \\
\hline & \multirow{2}{*}{$\begin{array}{l}\text { F } \\
\text { Lower }\end{array}$} & \multirow{2}{*}{$\begin{array}{l}\text { Sig. } \\
\text { Upper }\end{array}$} & \multirow{2}{*}{$\begin{array}{l}\mathrm{t} \\
\text { Lower }\end{array}$} & \multirow{2}{*}{$\begin{array}{l}\text { df } \\
\text { Upper }\end{array}$} & \multirow{2}{*}{\begin{tabular}{|l}
$\begin{array}{l}\text { Sig. } \\
\text { (2-tailed) }\end{array}$ \\
Lower
\end{tabular}} & \multirow{2}{*}{$\begin{array}{l}\begin{array}{l}\text { Mean } \\
\text { Difference }\end{array} \\
\text { Upper }\end{array}$} & \multirow{2}{*}{$\begin{array}{l}\text { Std. Error } \\
\text { Difference } \\
\text { Lower }\end{array}$} & \multicolumn{2}{|c|}{$\begin{array}{l}95 \% \text { Confidence } \\
\text { Interval of the } \\
\text { Difference }\end{array}$} \\
\hline & & & & & & & & Upper & Lower \\
\hline $\begin{array}{l}\text { Total } \\
\text { Equal } \\
\text { variances } \\
\text { assumed }\end{array}$ & 1.710 & .194 & -1.075 & 120 & .284 & -2.25833 & 2.10034 & -6.41686 & 1.90019 \\
\hline $\begin{array}{l}\text { Equal } \\
\text { variances } \\
\text { not } \\
\text { assumed }\end{array}$ & & & -1.032 & 74.406 & .306 & -2.25833 & 2.18923 & -6.62008 & 2.10341 \\
\hline
\end{tabular}

Table 3. Group Statistics

\begin{tabular}{|l|l|l|l|l|}
\hline Teachers and Students name & N & Mean & Std. Deviation & Std. Error Mean \\
\hline TEACHERS & 30 & 89.4333 & 7.64597 & 1.39596 \\
\hline STUDENTS & 92 & 84.4130 & 11.69874 & 1.21968 \\
\hline
\end{tabular}

Table 4. Independent Samples Test

\begin{tabular}{|c|c|c|c|c|c|c|c|c|c|}
\hline & \multicolumn{2}{|c|}{$\begin{array}{l}\text { Levene's Test for } \\
\text { Equality of } \\
\text { Variances }\end{array}$} & \multicolumn{7}{|c|}{ t-test for Equality of Means } \\
\hline & $\mathrm{F}$ & Sig. & $t$ & df & $\begin{array}{l}\text { Sig. } \\
\text { (2-tailed) }\end{array}$ & $\begin{array}{l}\text { Mean } \\
\text { Difference }\end{array}$ & $\begin{array}{l}\text { Std. Error } \\
\text { Difference }\end{array}$ & $\begin{array}{l}95 \% \mathrm{C} \\
\text { Interva } \\
\text { Differe }\end{array}$ & $\begin{array}{l}\text { dence } \\
\text { the }\end{array}$ \\
\hline & Lower & Upper & Lower & Upper & Lower & Upper & Lower & Upper & Lower \\
\hline $\begin{array}{l}\text { Total Equal } \\
\text { variances } \\
\text { assumed }\end{array}$ & 5.859 & .017 & 2.199 & 120 & .030 & 5.02029 & 2.28301 & .50009 & 9.54049 \\
\hline
\end{tabular}




\begin{tabular}{|l|l|l|l|l|l|l|l|l|l|}
\hline $\begin{array}{l}\text { Equal } \\
\text { variances not } \\
\text { assumed }\end{array}$ & & & 2.708 & 76.053 & .008 & 5.02029 & 1.85373 & 1.32831 & 8.71227 \\
\hline
\end{tabular}

Table 5. Group Statistics

\begin{tabular}{|l|l|l|l|l|}
\hline Departments & N & Mean & Std. Deviation & Std. Error Mean \\
\hline Sciences & 57 & 84.8947 & 11.43723 & 1.51490 \\
\hline Social Sciences & 65 & 86.3077 & 10.70473 & 1.32776 \\
\hline
\end{tabular}

Table 6. Independent Samples Test

\begin{tabular}{|c|c|c|c|c|c|c|c|c|c|}
\hline & \multicolumn{2}{|c|}{$\begin{array}{l}\text { Levene's Test for } \\
\text { Equality of } \\
\text { Variances }\end{array}$} & \multicolumn{7}{|c|}{ t-test for Equality of Means } \\
\hline & \multirow{2}{*}{$\begin{array}{l}\mathrm{F} \\
\text { Lower }\end{array}$} & \multirow{2}{*}{$\begin{array}{l}\text { Sig. } \\
\text { Upper }\end{array}$} & \multirow{2}{*}{\begin{tabular}{|l}
$\mathrm{t}$ \\
Lower
\end{tabular}} & \multirow{2}{*}{$\begin{array}{l}\text { df } \\
\text { Upper }\end{array}$} & \multirow{2}{*}{$\begin{array}{l}\text { Sig. } \\
\text { (2-tailed) } \\
\\
\text { Lower }\end{array}$} & \multirow{2}{*}{$\begin{array}{l}\text { Mean } \\
\text { Difference }\end{array}$} & \multirow{2}{*}{$\begin{array}{l}\begin{array}{l}\text { Std. Error } \\
\text { Difference }\end{array} \\
\text { Lower }\end{array}$} & \multicolumn{2}{|c|}{$\begin{array}{l}95 \% \text { Confidence } \\
\text { Interval of the } \\
\text { Difference }\end{array}$} \\
\hline & & & & & & & & Upper & Lower \\
\hline $\begin{array}{l}\text { Total } \\
\text { Equal } \\
\text { variances } \\
\text { assumed }\end{array}$ & .484 & .488 & -.704 & 120 & .482 & -1.41296 & 2.00563 & -5.38396 & 2.55805 \\
\hline $\begin{array}{l}\text { Equal } \\
\text { variances } \\
\text { not } \\
\text { assumed }\end{array}$ & & & -.701 & 115.464 & .484 & -1.41296 & 2.01441 & -5.40295 & 2.57704 \\
\hline
\end{tabular}

